TOMISLAV MIHETEC, Ph.D. ${ }^{1}$

(Corresponding author)

E-mail: tom@integra.dk

ANDRIJA VIDOVIĆ, Ph.D. ${ }^{2}$

E-mail: avidovic@fpz.hr

ZVONIMIR REZO, univ.bacc.ing.traff. ${ }^{2}$

E-mail: zvonimir.rezo@gmail.com

1 Integra Consult A/S

Trørødvej 63B, 2950 Vedbæk, Denmark

2 University of Zagreb,

Faculty of Transport and Traffic Sciences

Vukelićeva 4, 10000 Zagreb, Croatia
Traffic Policy

Preliminary Communication

Submitted: 24 Mar. 2017

Accepted: 21 Nov. 2017

\title{
ASSESSMENT OF SINGLE EUROPEAN SKY IMPLEMENTATION IN THE FUNCTIONAL AIRSPACE BLOCK CENTRAL EUROPE
}

\begin{abstract}
Implementation of Air Traffic Management (ATM) Master Plan-defined projects represents a prerequisite for the successful implementation of the Single European Sky initiative defined by the European Commission in 2004. The implementation of ATM-related projects is currently under the responsibility of the Single European Sky Research Programme Deployment Manager. While the definition of projects is being performed at the European Network level, the implementation is performed through sub-regional grouping of Air Navigation Service Providers in a form of Functional Airspace Blocks. This paper analyses the level of implementation of ATM-related projects in the Functional Airspace Block Central Europe and their relation to other Functional Airspace Blocks defined in Europe. From this paper it is obvious that even though the planning of Single European Sky projects is based on the collaborative implementation of Functional Airspace Block level, the real implementation is fragmented and based on national levels.
\end{abstract}

\section{KEY WORDS}

Air Traffic Management; single European sky; functional airspace block; master plan;

\section{INTRODUCTION}

With the liberalization of the European aviation market in late 1993, travellers using air transport could benefit from more accessible and competitive air transport arrangements. According to EUROCONTROL [1] in Europe air navigation services as such, are organized in a much more fragmented way than in the United States. When comparing the European and the United States Air Traffic Management system, it is visible that with almost the same volume of airspace (US CONUS airspace is $10 \%$ smaller than the European airspace) the US ATM system controlled approximately $57 \%$ more IFR flights with $24 \%$ fewer full time Air Traffic Controllers (ATCOs). In Europe, there are 37 Air Navigation Service Providers (ANSPs) with 62 en-route area control centres, while in the United States there are 20 en-route area control centres with only one ANSP [2]. The unit cost of the European system is between $60 \%$ and $70 \%$ higher than in the US [3]. The presented data clearly indicate that the fragmentation of the European air traffic system is one of the biggest reasons for the high level of delays. This fragmentation in the European airspace, where the airspace sectorisation is based on national borders (the existing Flight Information Regions), where flights fly on average $49 \mathrm{~km}$ longer than direct flight length, has estimated a cost of 4 billion euro a year [4].

The European Commission established High Level Group to support the preparation of concrete policy proposals and recommendations for the development of the aviation regulatory network in Europe - with a particular focus on Air Traffic management (ATM) and to provide a roadmap with practical next steps [5]. Based on the identified inefficiency the European Commission has launched a Single European Sky (SES) initiative with the scope to improve and reinforce safety and to restructure the airspace based on traffic instead of national frontiers. The objective of SES I and SES II regulations is to enhance the current safety standards and overall efficiency for general air traffic in Europe, to optimise the capacity meeting the requirements of all airspace users and to minimise delays [6].

The original SES Framework Regulation set out the overall objectives to enhance safety, improve efficiency and minimize delays. While SES provided the means for evaluation of air navigation performance, based on the EUROCONTROL work, SES did not directly address the real performance issue. Rather, it concentrated on creating a common regulatory framework and setting down some operational standards [7]. The SES II regulation was focused on defragmentation of the European airspace through the implementation of the Functional Airspace Blocks (FAB). FAB represents 
the airspace block based on operational requirements and established regardless of state boundaries, where the provision of air navigation services and related functions is performance-driven and optimised through enhanced cooperation among air navigation service providers or, when appropriate, an integrated provider $[8,9]$. According to Button and Neiva, one of the key components of the movement towards this is the notion of functional airspace blocks (FABs) whereby blocks of airspace are combined as a precursor to the total unification of the system [10]. According to Steiner et al., ATM regionalization is predicted, i.e. unification of several national air traffic management systems in the upper airspace, which should contribute to the reduction in the number of decision-makers at the national levels and complying with the guidelines of integration in the technological and conceptual-management sense [11].

In relation to SES initiative, the European Commission launched SESAR programme that is comparable to the NextGen ATM (modernisation programme launched in the United States). The ultimate goal of SESAR is to ensure sustainable air transport development in Europe in a safe and efficient manner through a performance-driven approach. The key performance targets are the following: enabling a three-fold increase in capacity; improving safety by a factor of 10; reducing by $10 \%$ the environmental impact per flight; cutting ATM costs by 50\% [12]. The development of today's ATM system in Europe is performed through the implementation of ATM Master Plan projects. Within the framework of the Single European Sky (SES), the European Air Traffic Management Master Plan (in extension of the paper 'the Master Plan') represents the main planning tool for setting ATM priorities and ensuring that the SESAR (Single European Sky ATM Research) Target Concept becomes a reality. In relation to the achievement of the SESAR goals, the European Commission launched the Pilot Common Projects (PCP) regulation in 2014. The Pilot Common Project identifies six ATM functionalities, namely, Extended Arrival Management and Performance Based Navigation in the High-Density Terminal Manoeuvring Areas; Airport Integration and Throughput; Flexible Airspace Management and Free Route; Network Collaborative Management; Initial System Wide Information Management; and Initial Trajectory Information Sharing. The deployment of these six ATM functionalities should be made mandatory [13]. For each of the 6 ATM functionalities and 20 sub-functionalities contained in the PCP, the SESAR Deployment Programme defines the families of Implementation Projects (IPs), explaining the implementation activities to be performed, indicating by which stakeholder, where, how and identifying the optimum time for their execution [14].
Monitoring of ATM functionalities and sub-functionalities deployment, performed by the implementation of specific projects, is done at the European level through the European Single Sky ImPlementation' (ESSIP) Plan and on local level through the Local Single Sky ImPlementation' (LSSIP) Plan.

The performance, management and regulation of Air Traffic Services represent those functions that are an absolute condition for the very existence of safe and efficient air transport [15].

The subject of this research paper is the evaluation of the local and regional ATM modernisation projects on FAB level in relation to the SESAR, Pilot Common Projects and ATM Master Plan. The purpose of this research is to make an analysis and assessment of the SES ATM modernisation projects implementation between the FAB CE Member States and between FAB $\mathrm{CE}$ and other FABs to evaluate the implementation of SES at FAB level.

\section{ATM MASTER PLAN IMPLEMENTATION METHODOLOGY IN EUROPE}

\subsection{ATM Master Plan Processes}

Master Plan represents an evolving roadmap of ATM developments and the result of strong collaboration between all stakeholders. This document outlines the vision and performance ambitions for the future ATM system within a timeframe until 2035 with an outlook towards 2050. It also prioritises the R\&D activities and solutions needed to achieve the predefined vision. As the technological pillar of the SES initiative, SESAR contributes to achieving the SES High-Level Goals and supports the SES regulatory framework [16].

The Master Plan details not only a high-level view of what is needed to be done to deliver a high-performing ATM system, but also explains why and until when. It therefore sets the framework for the development activities performed by the SESAR Joint Undertaking (SJU) in the perspective also of the deployment activities to be performed by all operational stakeholders under the coordination of the SESAR Deployment Manager and in accordance with the Deployment Programme to ensure overall consistency and alignment.

The content of the Master Plan is structured in three levels, to allow the stakeholders to access the information at the level of detail that is most relevant to their area of interest.

Level 1 represents the Executive view of the Master Plan that comprises an integrated set of information about performance ambition, SESAR key features, essential operational changes, ATM technology changes, deployment scenarios, ICAO blocks and standardisation \& regulatory needs. 
Levels 2 and 3 of the Master Plan provide more details on the operational changes and related elements and therefore the target audience are the expert-level stakeholders.

Level 2 represents Planning and architecture view and provides the detailed planning and architecture information supporting Level 1.

Level 3 is Implementation view and comprises the European Single Sky ImPlementation (ESSIP) Plan (and Report), which is a set of commonly-agreed implementation actions. In addition, Level 3 of the Master Plan provides stakeholders with a basis for shortterm common implementation planning.

It is widely recognised that to increase performance, ATM modernisation should look at the flight as a whole and not in segmented portions, as is the case today. Bearing this in mind, the vision is realised across the entire ATM system, offering improvements at every stage of the flight (Figure 1).

Single European Sky initiative throughout FAB concept seeks to contribute to the European airspace community in terms of increased safety, capacity, cost-effectiveness and reduced impact on the environment. In accordance with "Agreement on the establishment of Functional airspace block Central Europe", State Members are obligated to participate in jointly agreed objectives implementation plan. Implementation of objectives, which are divided into fourteen implementation areas, ensures progress towards achievement of the set goals. Objectives implementation areas include projects in the following areas/ categories: Airspace Organisation and Management, Airport Air Traffic Services, Air Traffic Control, Environment, General, Surveillance, Safety Regulation, Flow and Capacity Management, Aeronautical Information Management, Human Factors, Communications, Interoperability, Navigation and Safety Management.

\subsection{ESSIP and LSSIP Methodology}

The ‘European Single Sky ImPlementation' (ESSIP) Plan defines the common implementation actions required to improve the European ATM network over a short or medium term. The ESSIP represents the 'Level 3' of the European ATM Master Plan. It does it in the form of implementation objectives to be achieved within coordinated time scales, published every year in the ESSIP Plan. Its target audience includes planning staff from the various stakeholders participating in the ESSIP, both at the European and national level. ESSIP objectives bring tangible benefits to the European aviation community in terms of increased safety, capacity, cost-effectiveness or lesser impact on the environment [17].

The ESSIP mechanism provides a valuable instrument for States / NSAs to plan and monitor deployment since the ESSIP Plan is mirrored at the national level by the LSSIP (Local Single Sky ImPlementation) tool - which assists individual States / NSAs in their monitoring and reporting efforts in order to meet their objectives and national performance targets, whilst also providing a holistic view of the short/medium term deployments (Figure 2).

It is important to note that the scope of the ESSIP Plan includes also planning actions derived from implementing rules for interoperability as well as planning actions related to other elements of the Master Plan Level 2 mature for implementation.

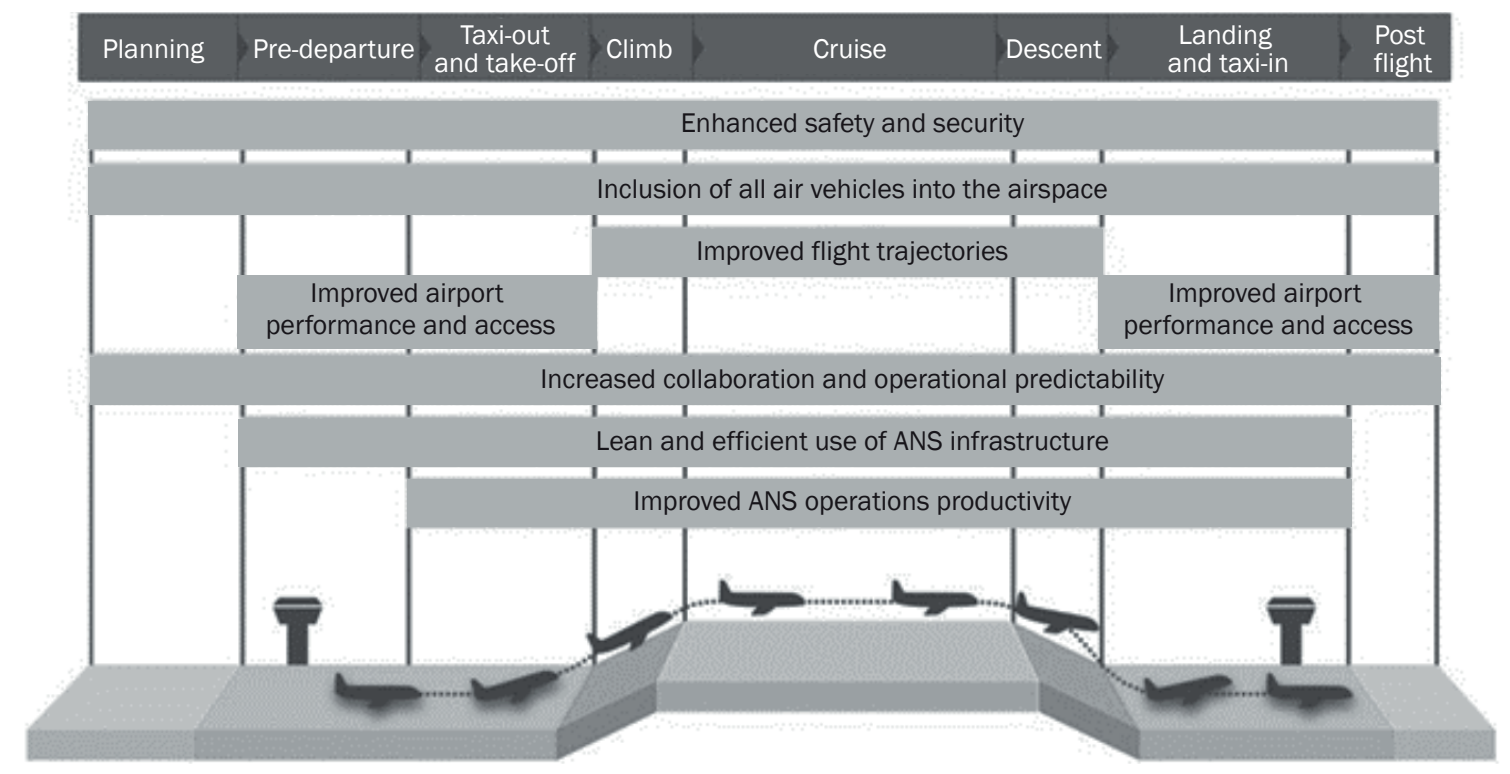

Figure 1 - Improvements at every stage of the flight Source: SESAR JU 


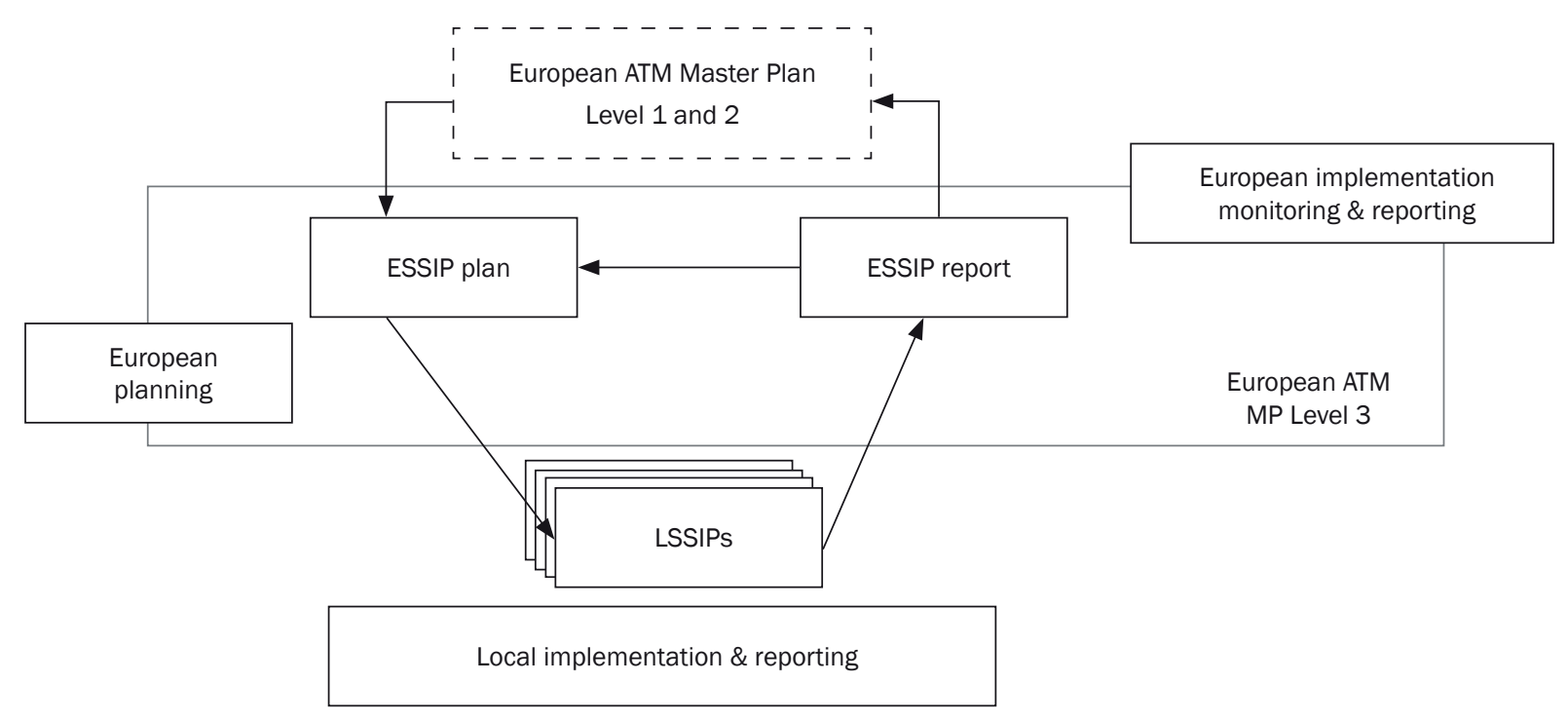

Figure 2 - Master Plan deliverables

With all its interdependencies, the ESSIP process is one of the tools available, which promotes, together with the SDM (Supplementary Data Message) tools, the links between the European implementation decisions and stakeholders' business plans and closes the loop between implementation reporting and implementation planning.

The Local Single Sky ImPlementation documents (LSSIPS), as an integral part of the ESSIP/LSSIP mechanism, constitute a short/medium term implementation plan containing ECAC States' actions to achieve the Implementation Objectives as set out by the ESSIP and to improve the performance of their national ATM System.

The LSSIP documents are structured into 6 chapters to better differentiate the Stakeholder(s) accountable for the information contained in each of them [18].

\section{ORGANISATIONAL AND OPERATIONAL OUTLOOK OF FAB CENTRAL EUROPE}

A key step towards reducing fragmentation in the European airspace has been the creation of nine FABs, grouping ANSPs together to improve airspace

Table 1 - FAB CE overview coordination, and introduce efficiencies [19]. One of FABs, Central Europe FAB (FAB CE), was established in May 2011 with the signature on the FAB CE Agreement on a state level [20]. The FAB CE comprises the following constituents shown in Table 1.

The responsibility for the FAB CE governance has been organised at the State and Air Navigation Service Provider (ANSP) level. The highest decision-making body is FAB CE Council (FCC) that is composed of representatives of the Contracting States (Ministries) and each FAB CE State has one vote. The National Supervisory Authority and the ANSPs may participate in the FAB CE Council as an observer.

There are two Committees supporting FCC in terms of military and supervisory activities within FAB CE. Joint Civil Military Airspace Coordination Committee (JCMACC) covers the civil-military cooperation with respect to the FAB CE aiming at strategic coordination of national ASM and airspace design policies, ATFCM processes and civil-military cooperation of all FAB CE States. National Supervisory Authorities Coordination Committee (NSA CC) is responsible for development and implementation of supervisory and all other tasks arising from the Single European Sky regulatory requirements [21].

\begin{tabular}{||l|l|l||}
\hline \multicolumn{1}{|c|}{ Member States } & \multicolumn{1}{c|}{ ANSP } & \multicolumn{1}{c||}{ NSA } \\
\hline \hline Republic of Austria & Austro Control & $\begin{array}{l}\text { Federal Ministry of Transport, Innovation and Technology, Civil Aviation } \\
\text { Authority of Austria }\end{array}$ \\
\hline Bosnia and Herzegovina & BHANSA & Bosnia and Herzegovina Directorate of Civil Aviation \\
\hline Republic of Croatia & Crocontrol & Croatian Civil Aviation Agency \\
\hline Czech Republic & ANS CR & Civil Aviation Authority of the Czech Republic \\
\hline Hungary & HungaroControl & National Transport Authority of Hungary \\
\hline Slovak Republic & LPS & Civil Aviation Authority of the Slovak Republic \\
\hline Republic of Slovenia & Slovenia Control & Civil Aviation Agency of the Republic of Slovenia \\
\hline
\end{tabular}



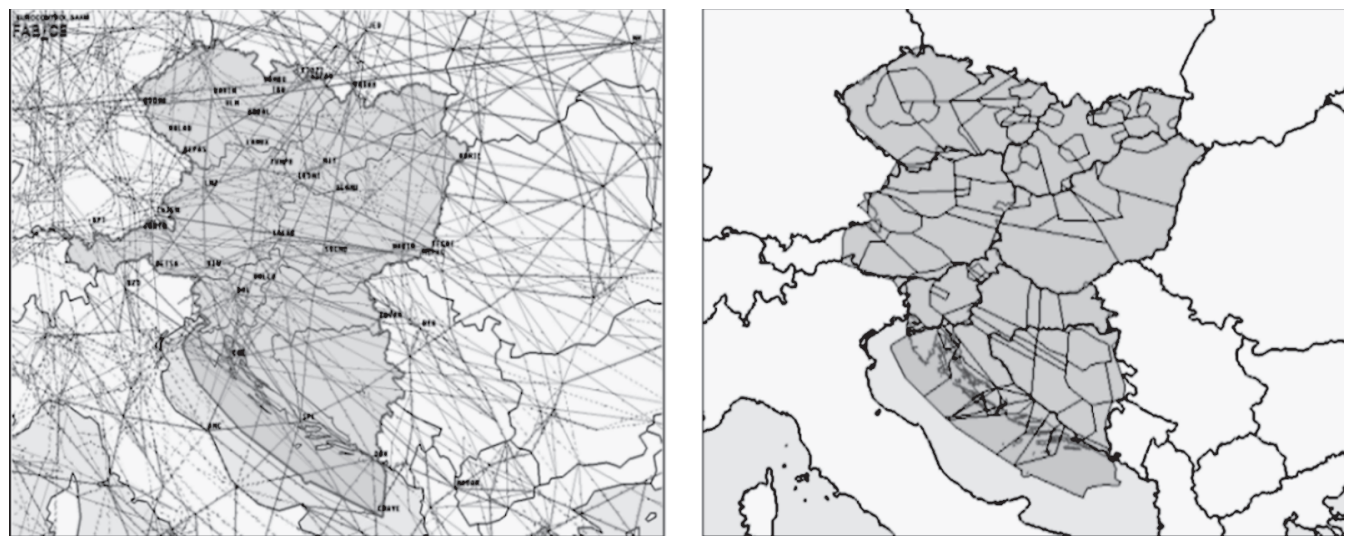

Figure 3 - FAB CE Geographical scope

Under the ANSP FAB CE governance structure level, FAB CE established a legal entity in October 2014, with the responsibility to support the implementation of the FAB CE programme. Still, the main high-level decision-making body is the CEO Committee (CEOC) responsible for taking all decisions with the purpose of ensuring better ANSP cooperation. In addition, there is also the Steering Committee as the superior body to the sub-committees and other structures, such as the Operational Sub-committee, Financial Sub-committee, Technical Sub-committee, Safety Sub-committee, Human Resources Sub-committee, etc.

According to the FAB CE Agreement not all FAB CE Member States have designated all ANS services at FAB level; for example, Austria, the Czech Republic and Hungary included ATS, CNS, AIS, SAR and MET services in the FAB scope while Bosnia and Herzegovina, Croatia, Slovakia and Slovenia only included the mandatory services defined in the FAB CE Agreement.

Concerning the airspace covered by the FAB scope, there is also a distinction in the volume of airspace designated as a FAB airspace per FAB Member States. From the Agreement, it is obvious that not all FAB CE Member States have included the lower part of its airspace in the FAB CE scope. The airspace included in the FAB CE is defined as follows: FIR Vienna, GND (Ground) - UNL (Unlimited), FIR Sarajevo, FL165 UNL; FIR Zagreb, F205 - UNL; FIR Prague, GND - UNL; FIR Budapest, GND - UNL; FIR Bratislava, FL195 UNL; FIR Ljubljana, FL175 - UNL (Figure 3). In addition, Figure 3 describes both the route network and elementary ACC sectors in FAB CE and it signifies the complexity of providing air traffic management services, due to the large number of elementary sectors and number of ATS routes.

The designated ANS providers in the FAB CE are as follows: Austro Control, BHANSA, CroControl, ANS CR, Hungarocontrol, LPS and Slovenia Control. From the operational perspective, there are currently 63 elementary sectors with the possibility of opening different airspace configurations and collapsing of those elementary sectors (as presented in Figure 3). The ANS services within the scope of the FAB CE Agreement are provided from the following Area Control Centres (ACC): ACC Bratislava; ACC Budapest; ACC Ljubljana; ACC Praha; ACC Sarajevo; ACC Vienna; ACC Zagreb [22].

Figure 4 presents the traffic evolution of overflights within the FAB CE airspace volume. It can be seen that traffic in $F A B C E$ has been growing, the same as in the year 2012 when the FAB CE was established, there were around 1,200,000 overflights while at the end of 2016 there were around 1,350,000 overflights representing an increase of $12.5 \%$ [23].

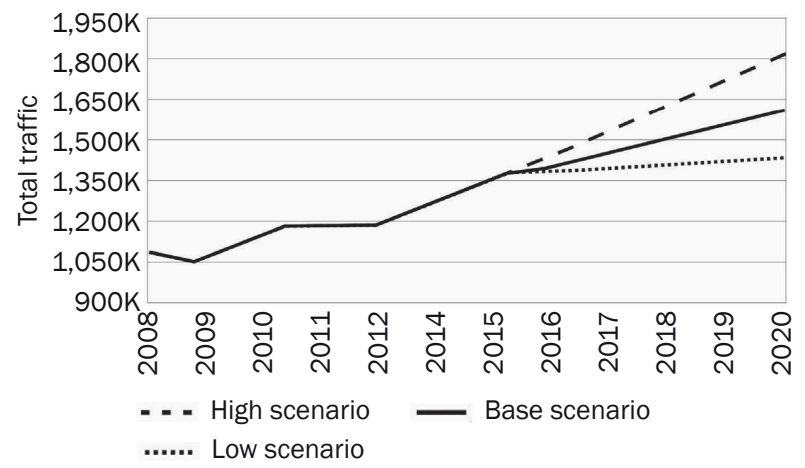

Figure 4 - FAB CE Overflight evolution

Table 2 represents traffic data from the EUROCONTROL forecast [24]. In 2016 it can be noticed that most of the traffic in FAB CE, according to the Base scenario, represented the Overflight (0) traffic with around 66\% of the total share of FAB CE traffic. Arrival/Departure (AD) holds around $30 \%$ of the total share and the Internal (I) traffic accounts for around $4 \%$ of the total FAB CE traffic. It is expected that the overall FAB CE traffic will see a growth, between 2016 and 2022, of around $15 \%$. 


\begin{tabular}{|c|c|c|c|c|c|c|c|c|c|c|c|c|}
\hline ָָ & $\begin{array}{l}\hat{D} \\
\infty \\
0 \\
\infty \\
\infty\end{array}$ & $\begin{array}{l}0 \\
0 \\
\circ \\
0 \\
0 \\
8\end{array}$ & $\begin{array}{l}\qquad \\
0 \\
0 \\
-1 \\
-1 \\
0 \\
-1\end{array}$ & 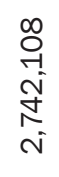 & 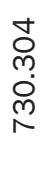 & $\begin{array}{l}\text { Oे } \\
\text { O. } \\
\stackrel{0}{\infty}\end{array}$ & 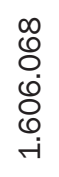 & 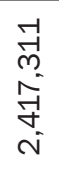 & 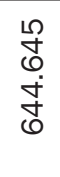 & $\begin{array}{l}8 \\
\stackrel{8}{ } \\
m \\
\\
\Gamma\end{array}$ & 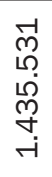 & 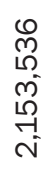 \\
\hline $\begin{array}{l}\text { సे } \\
\text { ํ. }\end{array}$ & 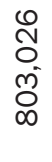 & $\begin{array}{l}\infty \\
\infty \\
\stackrel{0}{N} \\
N \\
\infty\end{array}$ & 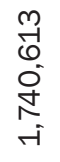 & 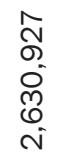 & \begin{tabular}{l} 
Dे \\
0 \\
-1 \\
\multirow{N}{N}{}
\end{tabular} & $\begin{array}{l}\stackrel{J}{J} \\
\stackrel{D}{N}\end{array}$ & 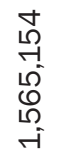 & 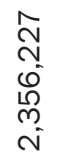 & $\begin{array}{l}\stackrel{1}{N} \\
N \\
\widetilde{N} \\
\tilde{0}\end{array}$ & $\begin{array}{l}\text { f } \\
\stackrel{S}{N} \\
\stackrel{N}{N}\end{array}$ & 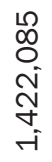 & 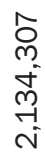 \\
\hline ণ্ণ & $\begin{array}{l}0 \\
0 \\
i \\
\infty \\
0 \\
0\end{array}$ & $\begin{array}{l}\stackrel{\llcorner}{f} \\
\underset{+}{+} \\
\stackrel{+}{\infty}\end{array}$ & 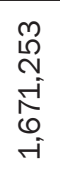 & $\begin{array}{l}m \\
N \\
\infty \\
\infty \\
N \\
N \\
0 \\
N\end{array}$ & 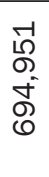 & $\begin{array}{l}\vec{\gamma} \\
\stackrel{-}{न} \\
\infty \\
\infty\end{array}$ & 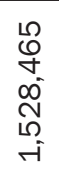 & 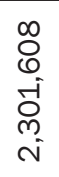 & $\begin{array}{l}\text { ○ } \\
\stackrel{9}{+} \\
10 \\
00 \\
0\end{array}$ & $\begin{array}{l}\infty \\
0 \\
\mathbb{N} \\
\mathbb{N} \\
N\end{array}$ & 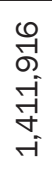 & 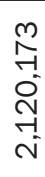 \\
\hline 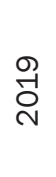 & 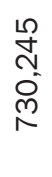 & $\begin{array}{l}\vec{H} \\
\underset{N}{-} \\
\infty\end{array}$ & 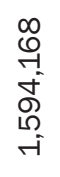 & $\begin{array}{l}+ \\
0 \\
0 \\
0 \\
0 \\
0 \\
+ \\
ن\end{array}$ & $\begin{array}{l}\vec{f} \\
\mathrm{~N} \\
\stackrel{0}{5} \\
6\end{array}$ & $\begin{array}{l}\hat{\beta} \\
10 \\
0 \\
0\end{array}$ & $\begin{array}{l}\text { m } \\
\Omega \\
1 \\
\infty \\
\infty \\
+ \\
+\end{array}$ & 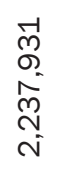 & 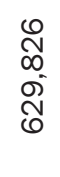 & $\begin{array}{l}\hat{\infty} \\
\stackrel{N}{N} \\
\stackrel{N}{N}\end{array}$ & 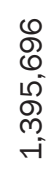 & 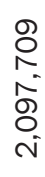 \\
\hline$\stackrel{\infty}{\stackrel{\sim}{\sim}}$ & $\begin{array}{l}\hat{0} \\
\stackrel{1}{0} \\
\infty \\
0 \\
0\end{array}$ & 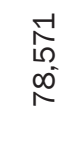 & 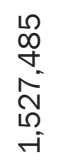 & 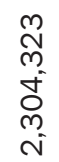 & $\begin{array}{l}\hat{0} \\
0 \\
0 \\
0 \\
0\end{array}$ & 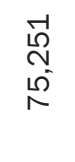 & 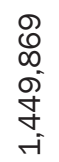 & 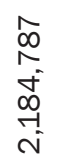 & 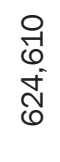 & \begin{tabular}{l}
$\infty$ \\
\multirow{N}{N}{} \\
\multirow{N}{N}{}
\end{tabular} & $\begin{array}{l}\infty \\
\infty \\
N \\
-1 \\
\infty \\
N \\
\sim \\
-1\end{array}$ & 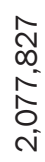 \\
\hline 亏े̀ & $\begin{array}{l}\stackrel{-1}{9} \\
\stackrel{-}{1} \\
0 \\
0\end{array}$ & $\begin{array}{l}\stackrel{5}{m} \\
\stackrel{2}{1} \\
\stackrel{\rho}{N}\end{array}$ & 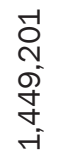 & 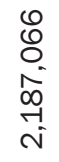 & 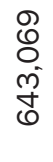 & $\begin{array}{l}\hat{\delta} \\
\stackrel{\circ}{N} \\
\text { N }\end{array}$ & 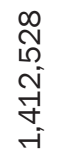 & 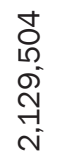 & 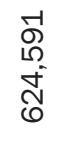 & $\begin{array}{l}-1 \\
0 \\
0 \\
N \\
N\end{array}$ & $\begin{array}{l}\mathcal{Y} \\
\infty \\
\infty \\
\tilde{Q} \\
\tilde{m} \\
-1\end{array}$ & $\begin{array}{l}\vec{J} \\
\stackrel{1}{0} \\
\text { N } \\
0 \\
\text { i }\end{array}$ \\
\hline $\begin{array}{l}0 \\
\stackrel{1}{\alpha} \\
\text {. }\end{array}$ & $\begin{array}{l}\circ \\
\stackrel{0}{0} \\
0 \\
\infty \\
0 \\
0\end{array}$ & 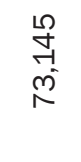 & $\begin{array}{l}\hat{0} \\
\sim \\
-1 \\
\infty \\
m \\
-1\end{array}$ & \begin{tabular}{l} 
N \\
$o$ \\
$o$ \\
10 \\
$\infty$ \\
0 \\
\multirow{1}{*}{}
\end{tabular} & $\begin{array}{l}\text { ⿵人 } \\
\infty \\
\stackrel{1}{0} \\
0\end{array}$ & $\begin{array}{l}\infty \\
N \\
\infty \\
N \\
N\end{array}$ & $\begin{array}{l}\text { Dे } \\
\infty \\
\infty \\
\infty \\
m \\
\text { - } \\
-i\end{array}$ & 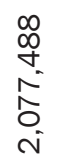 & 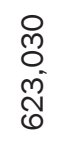 & \begin{tabular}{l}
$\mathbb{N}$ \\
\multirow{N}{N}{} \\
N
\end{tabular} & 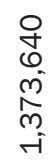 & 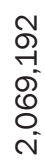 \\
\hline$\stackrel{n}{\circ}$ & 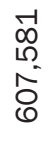 & $\begin{array}{l}\infty \\
\& \\
\infty \\
\sim \\
\sim\end{array}$ & 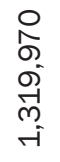 & 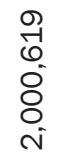 & $\begin{array}{l}-1 \\
0 \\
\stackrel{0}{0} \\
\stackrel{8}{8} \\
8\end{array}$ & $\begin{array}{l}\infty \\
0 \\
0 \\
\grave{N}\end{array}$ & $\begin{array}{l}\text { ․ } \\
\text { مे } \\
\text { बे } \\
\text { ले } \\
\text { - }\end{array}$ & $\begin{array}{l}\text { बे } \\
\overrightarrow{0} \\
\dot{8} \\
8 \\
0 \\
\text { i }\end{array}$ & $\begin{array}{l}-1 \\
\infty \\
10 \\
\stackrel{0}{0} \\
8\end{array}$ & $\begin{array}{l}\infty \\
0 \\
0 \\
\Gamma \\
\Gamma\end{array}$ & 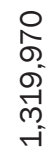 & $\begin{array}{l}0 \\
4 \\
0 \\
8 \\
0 \\
\text { i }\end{array}$ \\
\hline 离 & & & & & 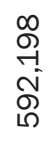 & 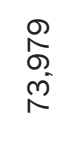 & 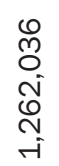 & \begin{tabular}{l}
$m$ \\
$\stackrel{m}{N}$ \\
$\infty$ \\
\multirow{N}{N}{} \\
$\stackrel{-}{-}$
\end{tabular} & & & & \\
\hline$\stackrel{m}{\stackrel{n}{N}}$ & & & & & $\begin{array}{l}0 \\
\tilde{ల} \\
0 \\
\infty \\
\infty \\
\infty\end{array}$ & $\begin{array}{l}\text { ने } \\
\text { mे } \\
\stackrel{N}{N}\end{array}$ & 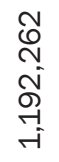 & $\begin{array}{l}\hat{-} \\
0 \\
\text { ⿵. } \\
\infty \\
\infty \\
-i\end{array}$ & & & & \\
\hline 곰 & & & & & $\begin{array}{l}0 \\
\stackrel{n}{1} \\
\text { ம. } \\
0\end{array}$ & $\begin{array}{l}m \\
\infty \\
\infty \\
\infty \\
\infty \\
1\end{array}$ & $\begin{array}{l}m \\
\infty \\
0 \\
0 \\
\infty \\
0 \\
-1 \\
-1\end{array}$ & 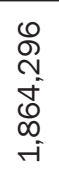 & & & & \\
\hline$\frac{O}{\frac{1}{a}}$ & 虽 & - & 0 & \multirow{2}{*}{ 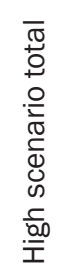 } & 是 & - & 0 & \multirow{2}{*}{ 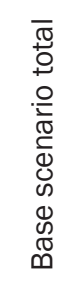 } & 安 & - & 0 & \multirow{2}{*}{ 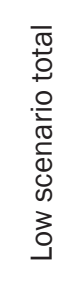 } \\
\hline 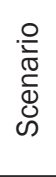 & & \multicolumn{2}{|c|}{ 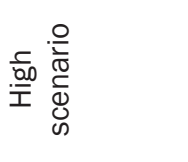 } & & & \multicolumn{2}{|l|}{ 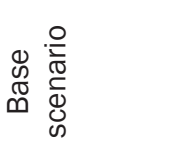 } & & & \multicolumn{2}{|c|}{ 3. } & \\
\hline
\end{tabular}


Table 3 presents the average annual traffic growth between 2016 and 2022 per FAB CE Member State. The traffic growth varies between the lowest annual traffic growth of $0.1 \%$ for Croatia to the highest traffic growth of $5.8 \%$ for Slovakia in 2016 . The overall traffic growth per annum for FAB CE is expected between $2.3 \%$ and $3.0 \%$. It should be noted that there is no decrease in traffic in all the FAB CE Member States, but the geopolitical situation (conflict in Ukraine and Syria) may additionally influence the traffic figures in FAB CE as it is positioned on one of the major traffic flows in Europe, the South-east traffic flow. From the perspective of the FAB CE Airspace Users it is interesting to evaluate the market share of the specific Airspace User categories (Figure 5).

The main users that fly through the FAB CE airspace are traditional scheduled airlines with more than the half of the market share. The second place belongs to the Low-cost airlines with almost 30\% in the year 2016 which makes them an influencing factor when setting up the financial framework of the Air Navigation Service Provider.

\section{ASSESSMENT OF ATM MASTER PLAN OBJECTIVES IMPLEMENTATION IN FAB CE}

During the past five years, thanks to the continuous improvements in the context of reliability and quality of information provided by national stakeholders, LSSIP documents have been used as a tool of "Performance Review Body". Therefore, taking into consideration the data published throughout "Local Plans of implementation of the Single European Sky" documentation, it is possible to make a comprehensive valorisation of the implementation of SES in FAB CE. The results of the conducted research presented in this chapter contain data analysed from 35 LSSIP documents covering each year between 2011-2015 for each FAB CE Member State [25]. These 35 documents are put under one reference [25] to keep literature review easier to follow. It should be noted that LSSIP document is a document containing Single European Sky implementation data published annually for only one Member State.

\subsection{FAB CE Objectives}

As it is mentioned before, Member States are obligated to participate in jointly agreed implementation plan which consists of objectives divided in fourteen categories. These projects differ with respect to who is responsible for their implementation. It is important to notice that in the same category it is possible to have more than just one stakeholder responsible for the implementation of an objective. Also, it is common practice that some objectives due to their complexity and comprehensiveness require participation of several stakeholders.

Table 3 - FAB CE traffic growth per member state [23]

\begin{tabular}{|l|l|l|l|l|l|l|l||}
\hline & 2016 & 2017 & 2018 & 2019 & 2020 & 2021 & 2022 \\
\hline \hline FAB CE & $2.3 \%$ & $2.7 \%$ & $2.7 \%$ & $2.7 \%$ & $3.0 \%$ & $2.4 \%$ & $2.6 \%$ \\
\hline Republic of Austria & $1.3 \%$ & $2.2 \%$ & $2.6 \%$ & $2.4 \%$ & $2.6 \%$ & $2.0 \%$ & $2.2 \%$ \\
\hline Bosnia and Herzegovina & $2.3 \%$ & $2.3 \%$ & $3.0 \%$ & $3.1 \%$ & $3.3 \%$ & $2.7 \%$ & $2.9 \%$ \\
\hline Republic of Croatia & $0.1 \%$ & $2.1 \%$ & $2.8 \%$ & $2.9 \%$ & $3.1 \%$ & $2.5 \%$ & $2.7 \%$ \\
\hline Czech Republic & $4.6 \%$ & $3.0 \%$ & $2.7 \%$ & $2.5 \%$ & $3.0 \%$ & $2.4 \%$ & $2.6 \%$ \\
\hline Hungary & $3.7 \%$ & $3.4 \%$ & $3.2 \%$ & $3.3 \%$ & $3.6 \%$ & $3.0 \%$ & $3.2 \%$ \\
\hline Slovak Republic & $5.8 \%$ & $3.5 \%$ & $3.1 \%$ & $3.3 \%$ & $3.5 \%$ & $3.0 \%$ & $3.2 \%$ \\
\hline Republic of Slovenia & $2.0 \%$ & $2.7 \%$ & $2.7 \%$ & $2.7 \%$ & $3.0 \%$ & $2.4 \%$ & $2.6 \%$ \\
\hline
\end{tabular}

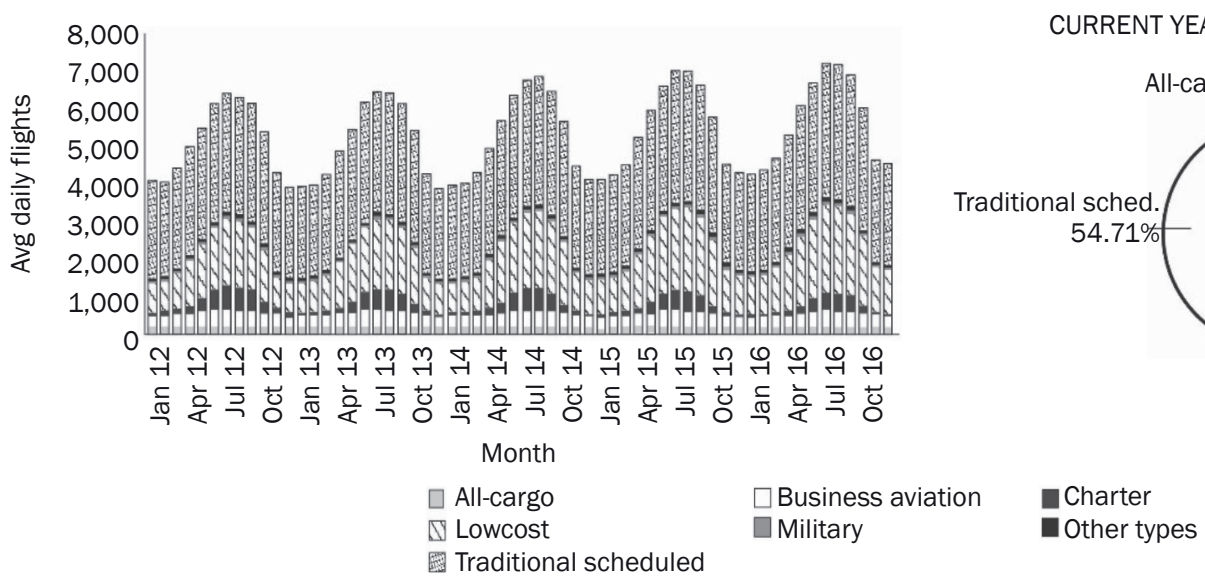

Figure 5 - FAB CE Market Share [23] 
Over time (2011-2016) LSSIPs and their objectives categories have changed. Some of the objective categories were added replacing the completed with the new ones. It is important to notice that objectives categories do not change strictly every year and for all Member States simultaneously. Objective categories replacement is conducted based on their implementation. For example, it is possible that one Member State is currently implementing an objective or objective category which another Member State implemented in its ATM system five years ago.

Every objective represented in LSSIPs is supported with applicable legislation and area(s), timescale(s); initial and full operational capability - FOC Date, Stakeholder Lines of Action - SloA, scope and expected performance benefits. Depending on who is obligated to carry out objectives implementation, the objectives are classified into Airport-related and State-related ones.

Airport-related objective categories include Airspace Organization and Management (AOM), Airport Air Traffic Services (AOP) and Environment (ENV).

- Airspace Organization and Management includes objectives such as implementation of ATS Route Network (ARN), Advanced Airspace Management, Direct Routing, Free Route Airspace and harmonization of Operational Air Traffic (OAT) and General Air Traffic (GAT) handling.

- Airport Air Traffic Services objectives category consists of the implementation of Advanced Surface Movement Guidance and Control System (A-SMGCS), implementation of airside capacity enhancement method and best practices based on EUROCONTROL capacity and efficiency implementation manual, implementation of Airport Airside Capacity Planning Method, Airport Collaborative Decision Making, Optimized Dependent Parallel Operations and improvement of runway safety by preventing runway incursions.

- Environment (ENV) includes implementation of Continuous Descent Operations (CDO) techniques for environmental improvements and implementation of Collaborative Environmental Management (CEM) at Airports.

Communications (COM), Flow and Capacity Management (FCM), Aeronautical Information Management (INF), Interoperability (ITY), Navigation (NAV), Safety Management (SAF), General (GEN), Surveillance (SUV), Safety Regulation (SRC) and HUM (Human Factor) represent State-related objectives categories, while Air Traffic Control (ATC) category includes both, Airport- and State-related objectives. The following group of objectives covers objectives categories mentioned above:

- COM; migration to ATS digital signalling for ground telephone applications and migration of ground international or regional X.25 data networks or services to the Internet Protocol (IP), migration from AFTN to AMHS, implementation of Voice over Internet Protocol (VoIP) in ATM.

- FCM; implementation of enhanced tactical flow management services, collaborative flight planning, Short-Term ATFCM Measures, interactive rolling NOP, Traffic Complexity Assessment.

- INF; implementation of integrated briefing and Electronic Terrain and Obstacle Data (TOD).

- ITY; applying a common flight message transfer protocol (FMTP), initial ATC air-ground data link services above FL-285, Air-Ground voice channel spacing above FL-195, implementation of groundground automated co-ordination processes, ensuring quality of aeronautical data and aeronautical information, aircraft identification, implementation of $8,33 \mathrm{kHz}$ air-ground voice channel spacing below FL195 and Surveillance performance and interoperability.

- NAV; implementation of P-RNAV and APV procedures. SAF; improvement of runway safety by preventing runway excursions and implementation of measures to: reduce the risk of level bust occurrences, prevent air/ground communications induced safety occurrences and to reduce the risk to aircraft operations caused by airspace infringements.

- GEN; implementation of European ANS contingency measures for Safety Critical Modes of Operation.

- SUR; implementation of Mode S elementary and enhanced surveillance and improvement of ground-based surveillance using ADS-B in Non-Radar Airspace (NRA). SRC; implementation of: Safety Regulatory Auditing by National Supervisory Authorities (NSA), Safety Oversight of Changes to ATM by National Supervisory Authorities (NSA), ATM Safety Oversight Capabilities by NSAs, EUROCONTROL Safety Regulatory Requirements (ESARRs) and Safety Levels and Resolution of Deficiencies.

- HUM; ensuring timely availability of ATCOs, integration of Human Factors into ATM Operations and into the lifecycle of ATM systems.

- ATC State-related objective - implementation of AMAN tools and procedures, while ATC State-related objectives include implementation of: arrival management tools, ground based safety nets: Short Term Conflict Alert (STCA), Area Proximity Warning, Minimum Safe Altitude Warning, Approach Path Monitor, automated support for conflict detection and conformance monitoring, ACAS II compliant with TCAS II, implementation of, in En-Route operations, information exchange mechanisms, tools and procedures in support of Basic AMAN operations and Electronic Dialogue as Automated Assistance to Controller during Coordination and Transfer. 
The mentioned objectives are analysed per each FAB CE Member State in the period 2011-2015 and the outcomes are explained and graphically presented.

The valorisation of the implementation of SES Initiative in FAB CE's Member States was carried out in 2016 and it contained data from 2011 to 2015. By defining the annual values of objective characteristics and with comparative numerical display, Table 4 shows the progress of SES objective implementation in the context of the Functional Airspace Block Central Europe in the period from 2011 to 2015.

According to the data of the previous movements of the objective's characteristics, the objectives defined as "Completed" are expected to have a positive growth trend in the following years. Also, the objectives classified as "Planned" are expected to remain at approximately the same value through the next years because the implemented objectives complement each other.

After the "Full operational capability" - FOC Date is passed and the objective is still not implemented, its characteristic is changed into "Late". Unfortunately, such a scenario occurs in all Member States implementation processes and that results in increased value rates of the objectives with delays in implementation at the FAB CE level. Table 1 shows the continuous annual increase of the objectives with delays in implementation. From the mentioned above, it can be concluded that it is necessary to additionally coordinate updates of ESSIP objectives with goals of proper and equal objectives implementation in all segments of air traffic management.

Analysing the results of samples defined as "No plan" objectives, it can be concluded that they represent a constant value which oscillates slightly. The reason for such behaviour can be found in the fact that FAB CE consists of seven Member States, making it next to the FAB EC, the Functional Airspace Block with the highest number of Member States. Because of the mentioned complexity and the regulatory-institutional framework within the $\mathrm{FAB} C \mathrm{CE}$, constant values of the objectives defined as "No plan" objectives are expected.

A positive change of value was recorded in 2015 when only 17 out of 289 objectives were classified as "Not Applicable". Considering that the Member States throughout the last period have invested significant resources and time to implement the objectives, this positive trend is expected to continue.

LSSIP objectives are separated into objectives regulated by State-related level and Airport-related level. The greatest number of FAB CE's objectives at Airport-related level are characterized as "Not Applicable“ objectives and they appear as a dominant value. By summing the data of all Member States and analysing indicators of objectives implementation at the State-related level, the greatest current value of FAB CE is occupied with objectives defined as "Planned" and as such appear in almost all segments of air traffic management. The most complex segments at the FAB CE level in which all six objective's characteristics occur are segments of Air Traffic Control and segment of Flow and Capacity Management. It should be noted that the number of State-related objectives defined as "Not Applicable" is almost negligible compared to the value of the same characteristic at the Airport-related level.

The efficiency rate equation can be expressed as comparison of the number of objectives which have been declared as completed and the overall number of objectives. A high level of efficiency implies a minimal amount of wasted time, effort, capacity, materials, etc. The Efficiency rate formula in this case is:

$$
\text { Efficiency rate }=\left(\frac{\sum \text { Completed Objects }}{\sum \text { All Objects }}\right) \cdot 100
$$

By profiling percentages of successfully completed objectives implemented in the FAB CE's Member States, Figure 6 can be seen as an equivalent to the level of maturity of the ATM systems of the Member States in achieving the SES Initiative.

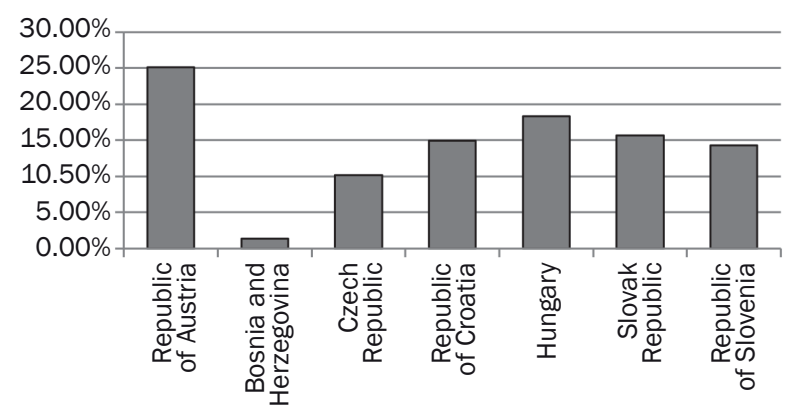

Figure 6 - Comparative overview of FAB CE's Member States efficiency rate

Table 4 - FAB CE annual movements of objective's characteristics

\begin{tabular}{||c|c|c|c|c|c|c||}
\hline \hline & Objective completed & $\begin{array}{c}\text { Objective partly } \\
\text { completed }\end{array}$ & $\begin{array}{c}\text { Objective } \\
\text { planned }\end{array}$ & Late & No plan & Not applicable \\
\hline \hline 2011 & $22.16 \%$ & $12.24 \%$ & $26.24 \%$ & $19.24 \%$ & $5.25 \%$ & $14.87 \%$ \\
\hline 2012 & $20.56 \%$ & $9.06 \%$ & $35.89 \%$ & $15.33 \%$ & $7.67 \%$ & $11.49 \%$ \\
\hline 2013 & $21.46 \%$ & $3.83 \%$ & $37.55 \%$ & $16.86 \%$ & $5.75 \%$ & $14.55 \%$ \\
\hline 2014 & $24.24 \%$ & $5.68 \%$ & $32.2 \%$ & $21.21 \%$ & $4.17 \%$ & $12.5 \%$ \\
\hline 2015 & $23.88 \%$ & $7.27 \%$ & $35.29 \%$ & $22.15 \%$ & $5.54 \%$ & $5.87 \%$ \\
\hline
\end{tabular}




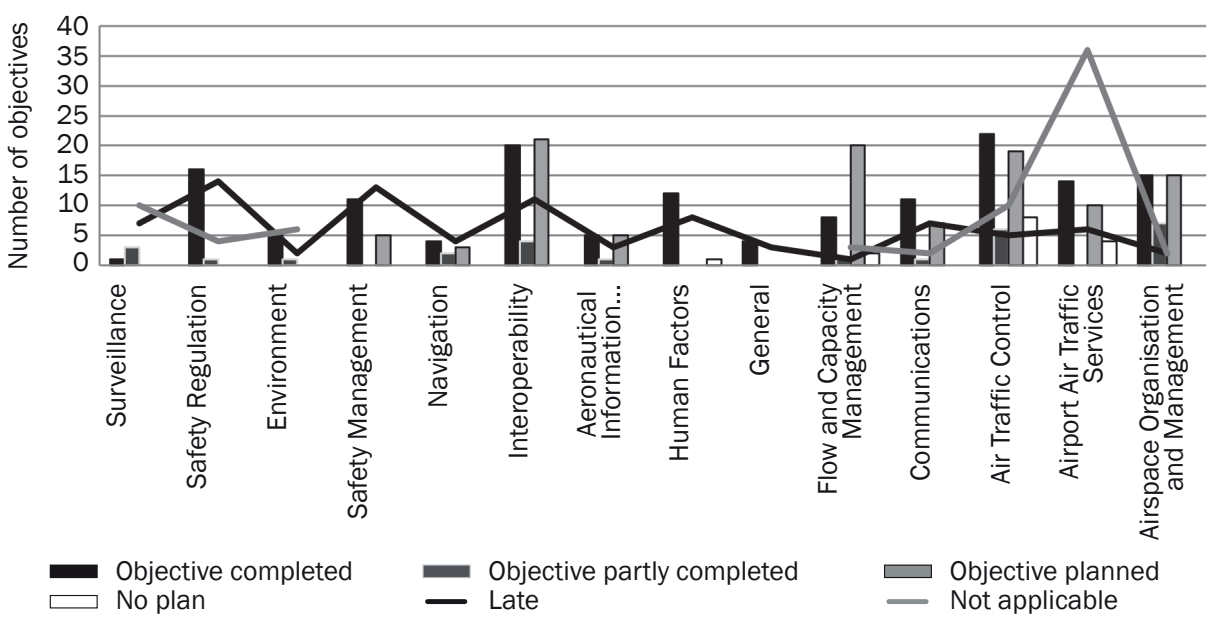

Figure 7 - Valorisation review of implementation of ESSIP Objectives per ATM segments in the period 2011 - 2015

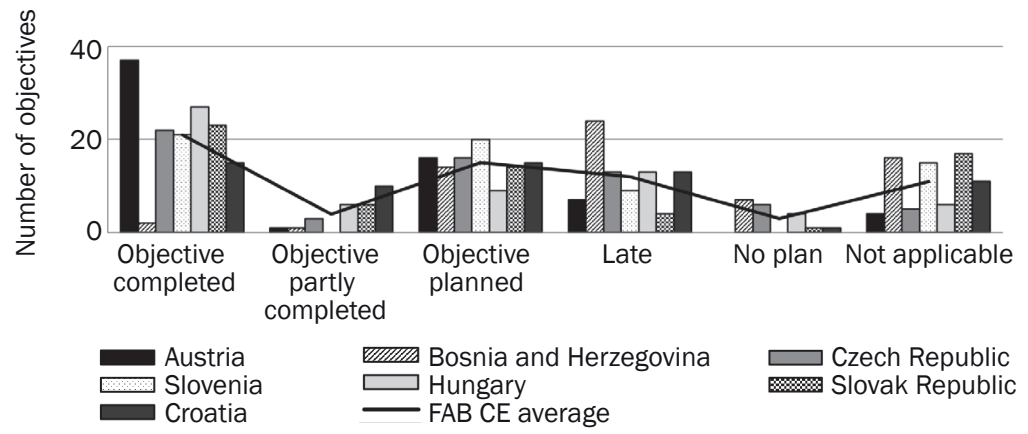

Figure 8 - FAB CE's 2011 - 2015 ESSIP Objectives implementation review

Figure 7 presents the valorisation of the implementation of LSSIP objectives for a five-year period (20112015) according to certain implementation aspects of air traffic management. In the data set, Airport Air Traffic Services - AOP, classified as "Not Applicable“, this characteristic emerges as the dominant value.

By the data presented in Figure 8, it can be concluded that there are significant differences between Sate Members in the implementation of the SES Initiative. This fact, because of its complexity, significantly slows down and threatens the establishment of Functional Airspace Block Central Europe. Not solving the problems arising from the implementation process and delaying objectives will result in postponement of deadlines for the establishment of Functional Airspace Block Central Europe and thus delay the implementation of the SES Initiative.

\subsection{Comparative Analysis of Implementation of FAB CE Master Plan Objectives with other FABs}

The European airspace has been divided into nine Functional Airspace Blocks (FABs). Two of nine FABs have been already implemented (UK-Ireland and Den-
mark-Sweden FABs) while others are still under development. Table 5 shows nine FABs and their Member States.

ESSIP Compliance Rate is an indicator introduced in ESSIP Report for 2011. Thanks to the ESSIP Compliance Rate formula, it is possible to monitor and to measure the level of compliance between the local implementation plans and the European Plan. ESSIP Compliance Rate represents a formula based on which the results will be forwarded to the Member States. It represents a EUROCONTROL mechanism, developed to explore the possibilities of supporting Member States in the implementation activities, in order to increase the level of compliance with ESSIP Plan, representing Level 3 of the European ATM Master Plan. ESSIP Compliance Rate formula is expressed as [27]:

$C=\frac{(X+0.8 \cdot Y+0.5 \cdot Z)}{(Q-K)}$

where capital letters represent:

C - ESSIP Compliance Rate

$X$-Sum of objectives completed

$Y$-Sum of objectives partly completed

$Z$-Sum of objectives planned

$Q$ - Total number of objectives

K -Sum objectives not applicable 
Table 5 - FABs and its Member States [26]

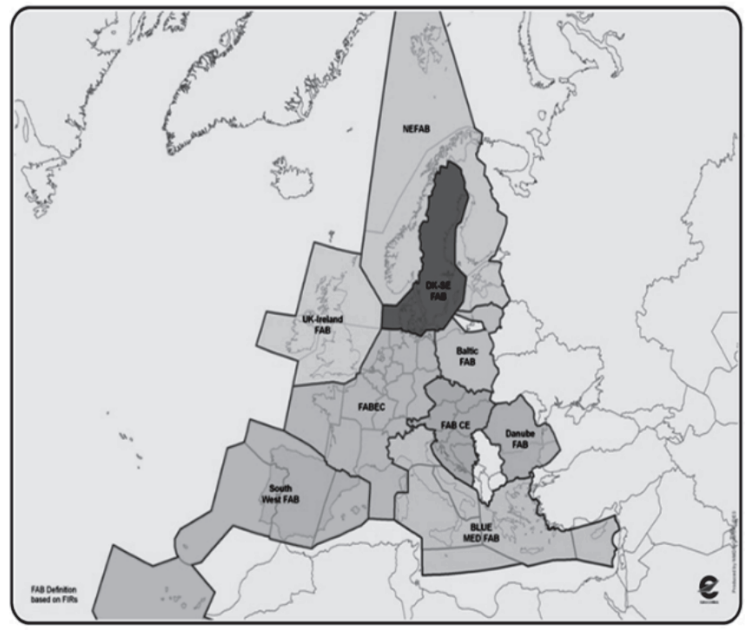

\begin{tabular}{|c|c|}
\hline \multirow{2}{*}{ South West FAB } & Portugal (PT) \\
\hline & Spain (ES) \\
\hline \multirow{2}{*}{ UK-Ireland FAB } & United Kingdom (UK) \\
\hline & Ireland (IE) \\
\hline \multirow{6}{*}{ FAB Europe Central } & France (FR) \\
\hline & Germany (DE) \\
\hline & Belgium (BE) \\
\hline & Netherlands (NL) \\
\hline & Luxemburg (LU) \\
\hline & Switzerland $(\mathrm{CH})$ \\
\hline \multirow{2}{*}{ DK/SE FAB } & Denmark (DK) \\
\hline & Sweden (SE) \\
\hline \multirow{4}{*}{ North European FAB } & Estonia (EE) \\
\hline & Finland $(\mathrm{FI})$ \\
\hline & Latvia (LV) \\
\hline & Norway (NO) \\
\hline \multirow{2}{*}{ Baltic FAB } & Poland (PL) \\
\hline & Lithuania (LT) \\
\hline \multirow{6}{*}{ FAB Central Europe } & Austria (AT) \\
\hline & Bosnia and Herzegovina (BA) \\
\hline & Czech Republic (CZ) \\
\hline & Croatia (HR) \\
\hline & Hungary (HU) \\
\hline & Slovenia (SI) \\
\hline \multirow{2}{*}{ Danube FAB } & Bulgaria (BG) \\
\hline & Romania (RO) \\
\hline \multirow{5}{*}{ Blue Med FAB } & Italy (IT) \\
\hline & Malta (MT) \\
\hline & Greece (GR) \\
\hline & Cyprus (CY) \\
\hline & Albania (AL) \\
\hline
\end{tabular}

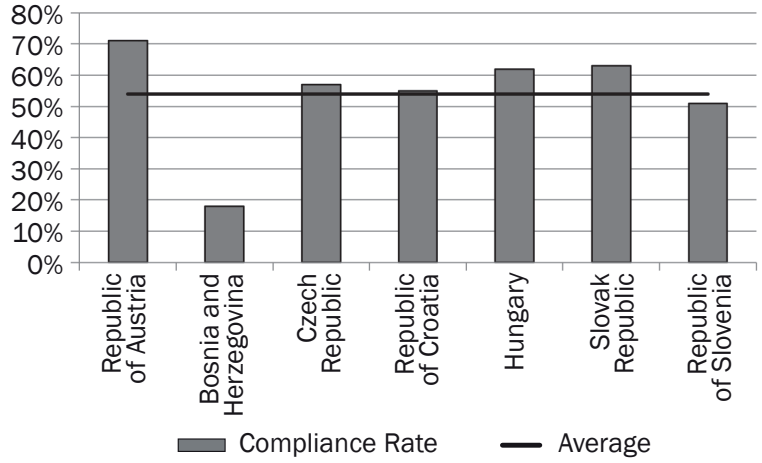

Figure 9 - Compliance Rate of FAB CE's Member States

Figure 9 represents the Compliance Rate of FAB CE's Member States with the European ATM Master Plan Volume 3. The mentioned figure also defines an average of Compliance Rate in FAB CE which is at the value of $53.86 \%$. From Figure 9 it is visible that Bosnia and Herzegovina is well behind with the implementation of LSSIP projects due to slow governance mechanisms. Other FAB CE states are within the average whereas the Republic of Austria is presented as a leader, with more than $70 \%$ of the implementation of modern technologies and processes.

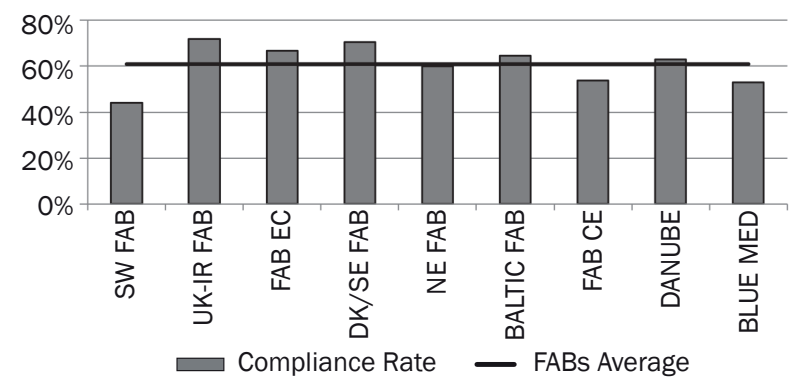

Figure 10 - FAB-related Master Plan Level 3 Compliance Rate (year 2015)

By considering the Compliance Rate of all FABs Member States with European ATM Master Plan Volume 3 , it is possible to define total rate of compliance. Figure 10 presents the overall Compliance Rate of all FABs with the European ATM Master Plan Volume 3 and its average value of $60.84 \%$. It can be concluded that still FAB CE is behind schedule in reaching the average compliance rate in comparison to other FABs.

\section{CONCLUSION}

Seven FAB CE Member States with their own difficulties in implementation of the "Single European Sky" represent just one of nine Functional Airspace Blocks. The number of States and the number of FABs best describes the comprehensiveness of the Initiative. The research has proved that it is not correct to expect that all Member States will simultaneously and equally implement ESSIP objectives. Nevertheless, 
Member States should - as much as possible, respect the agreed implementation deadlines. Based on the evaluation of implementation of the SES in the Functional Airspace Block Central Europe, it is possible to conclude that the current problem of effective implementation of the Single European Sky does exist.

The Central Europe's airspace is of great importance in the context of the European air traffic management. Therefore, any improvements achieved in the design, management or the provision of air navigation services contributes to a better traffic flow in Central Europe and on the whole European continent level. If the Member States want to implement the idea of establishing a unified Functional Airspace Block Central Europe, their efforts and successes in the implementation must be seen through the prism of the future and on the broader scale, whereas Inter-FAB cooperation is also needed.

\section{Dr. SC. TOMISLAV MIHETEC ${ }^{1}$}

E-mail: tom@integra.dk

Dr. Sc. ANDRIJA VIDOVIĆ ${ }^{2}$

E-mail: avidovic@fpz.hr

ZVONIMIR REZO, univ.bacc.ing.traff. ${ }^{2}$

E-mail: zvonimir.rezo@gmail.com

1 Integra Consult A/S

Trørødvej 63B, 2950 Vedbæk, Danmark

2 Sveučilište u Zagrebu, Fakultet prometnih znanosti

Vukelićeva 4, 10000 Zagreb, Hrvatska

\section{PROCJENA IMPLEMENTACIJE JEDINSTVENOG EUROPSKOG NEBA U FUNKCIONALNOM BLOKU SREDIŠNJE EUROPE}

\section{SAŽETAK}

Implementacija projekata definiranih u sklopu ATM Master plana predstavlja osnovu za uspješnu implementaciju inicijative Jedinstvenog europskog neba, definirane 2004. godine od strane Europske komisije. Implementacija ATM projekata je trenutno pod odgovornošću "Single European Sky Research Programme Deployment" upravitelja. Dok se definicija projekata izvršava na razini europske mreže, implementacija se provodi na sub-regionalnim grupama Pružatelja usluga u zračnoj plovidbi, formiranih u sklopu Funkcionalnih blokova zračnog prostora. Ovaj rad analizira razinu implementacije ATM projekata u sklopu Funkcionalnog bloka zračnog prostora centralne Europe $i$ prikazuje komparativnu razinu implementacije $u$ odnosu na razinu implementacije ostalih Funkcionalnih blokova zračnog prostora u Europi. Iz ovog rada očigledno je da iako je planiranje projekata Jedinstvenog europskog neba temeljeno na kolaborativnoj implementaciji na razini Funkcionalnih blokova zračnih prostora, stvarna provedba je fragmentirana i temeljena na nacionalnim razinama.

\section{KLUUČNE RIJEČI}

upravljanje u zračnom prometu; jedinstveno europsko nebo; funkcionalni blok zračnog prostora; Master Plan;

\section{REFERENCES}

[1] EUROCONTROL. The Single European Sky Fact Sheet. Brussels: EUROCONTROL; 2011.

[2] European Commission. Comparison of Air Traffic Management-Related Operational Performance: U.S./Europe. Brussels: EUROCONTROL; 2016.

[3] Crespo CD, Fenoulhet T. The Single European Sky (SES): Building Europe in the Sky. In: Crespo, CD, De Leon PM, editor. Achieving the Single European Sky, Goals and Challenges. Alphen aan den Rijn, The Netherlands: Kluwer Law International, 2011; p. 3-9.

[4] European Commission. Single European Sky [Internet]. [cited 2017 Feb 14]. Available from: https://ec.europa.eu/transport/modes/air/single-european-sky

[5] Bakker JT. Single European Sky: The Challenge of Managing Change. In: Crespo, CD, De Leon PM, editor. Achieving the Single European Sky, Goals and Challenges. Alphen aan den Rijn, The Netherlands: Kluwer Law International, 2011; p. 11-16.

[6] EUR-LEX. Framework for Creation of the Single European Sky (SES) [Internet]. [cited 2017 Feb 15]. Available from: http://eur-lex.europa.eu/legal-content/EN/ TXT/?uri=URISERV:I24020

[7] Lambert A, Johnson T. Performance Review: Implementation. In: Crespo, CD, De Leon PM, editor. Achieving the Single European Sky, Goals and Challenges. Alphen aan den Rijn, The Netherlands: Kluwer Law International, 2011; p. 137-146.

[8] EUROCONTROL. FABs [Internet]. [cited 2017 Feb 15]. Available from: https://www.EUROCONTROL.int/dossiers/fabs

[9] De Almeida LF. ICAO and the Pan European Dimension: The Single European Sky from a Global Perspective. In: Crespo, CD, De Leon PM, editor. Achieving the Single European Sky, Goals and Challenges. Alphen aan den Rijn, The Netherlands: Kluwer Law International, 2011; p. 79-89.

[10] Button K, Neiva R. Single European Sky and the functional airspace blocks: Will they improve economic efficiency?. Journal of Air Transport Management, 2013;33: 73-80. doi: 10.1016/j.jairtraman.2013.06.012

[11] Steiner S, Galović B, Radačić Ž. Strategic Framework of Air Traffic Development Promet - Traffic \& Transportation. 2008;20(3): 157-167.

[12] European Commission. Welcome to the SESAR project [Internet]. [cited 2017 Feb 16]. Available from: https:// ec.europa.eu/transport/modes/air/sesar

[13] European Commission. Commission Implementing Regulation (EU) No 716/2014 on the establishment of the Pilot Common Project supporting the implementation of the European Air Traffic Management Master Plan. Brussels: European Commission; 2014.

[14] SESAR Joint Undertaking. Deployment Programme 2016: Executive summary. Brussels: SESAR Joint Undertaking; 2016.

[15] McMillyn D, Van Dam R. EUROCONTROL and the EU Single European Sky. In: Crespo, CD, De Leon PM, editor. Achieving the Single European Sky, Goals and Challenges. Alphen aan den Rijn, The Netherlands: Kluwer Law International, 2011; p. 67-78.

[16] SESAR Joint Undertaking. The Roadmap for Delivering 
High Performing Aviation for Europe, European ATM Master Plan, Executive View. Brussels, Belgium; 2015.

[17] SESAR Joint Undertaking. The Roadmap for Delivering High Performing Aviation for Europe, European ATM Master Plan, Implementation View, ESSIP Plan. Brussels, Belgium; 2015.

[18] EUROCONTROL. Local Single Sky ImPlementation (LSSIP) CROATIA. Brussels, Belgium; 2015.

[19] Stelle P. SES Environmental and Efficiency Benefits: Reduction of Emissions. In: Crespo, CD, De Leon PM, editors. Achieving the Single European Sky, Goals and Challenges. Alphen aan den Rijn, The Netherlands: Kluwer Law International, 2011; p. 167-178.

[20] The Republic of Austria, Bosnia and Herzegovina, The Republic of Croatia, The Czech Republic, The Republic of Hungary, The Slovak Republic, The Republic of Slovenia. Agreement on the Establishment of Functional Airspace Block Central Europe. Brdo pri Kranju: FAB CE; 2011.

[21] Federal Ministry of Transport, Innovation and Technology, Civil Aviation Authority of Austria, Bosnia and Herzegovina Directorate of Civil Aviation, Croatian Civil Aviation Agency, Civil Aviation Authority of Czech Republic, National Transport Authority of the Republic of Hungary, Civil Aviation Authority of the Slovak Republic, Civil Aviation Agency of the Republic of Slovenia. National Supervisory Authorities Co-operation Agreement. Bratislava: FAB CE; 2011.

[22] Agencija za pružanje usluga u vazdušnoj plovidbi Bosne i Hercegovine, Austro Control Österreichische
Gesellschaft für Zivilluftfahrt mit beschränkter Hauftung, Hrvatska kontrola zračne plovidbe d.o.o., HungaroControl, Kontrola zračnega promete Slovenije d.o.o., Letové prevádzkové služby Slovenskej republiky, Řizeni letového provozu České republiky. Cooperation Agreement on the FAB CE Air Navigation Service Providers. Brdo pri Kranju: FAB CE; 2011.

[23] EUROCONTROL STATFOR Database. [Internet]. [cited 2017 Feb 23] Available from: https://ext.EUROCONTROL.int/analytics/saw.dll?Dashboard

[24] EUROCONTROL. EUROCONTROL Seven-Year Forecast Flight Movements and Service Units 2017-2023. Brussels: EUROCONTROL; 2017.

[25] EUROCONTROL. Local Single Sky Implementation (LSSIP) [Internet]. Documents covering years 2011-2015 for each of the following FAB CE Member States: Republic of Austria, Bosnia and Herzegovina, Republic of Croatia. Czech Republic, Hungary, Slovak Republic, Republic of Slovenia - composition of 35 individual documents [cited 2017 Jan 13]. Available from: http:// wWw.EUROCONTROL.int/articles/Issip

[26] EUROCONTROL. What are the FAB (Functional Airspace Blocks)?. [image on the Internet]. 2017 [cited 2017 Jan 13]. Available from: https://www.EUROCONTROL.int/faq/what-are-fab-functional-airspace-blocks

[27] EUROCONTROL. ESSIP REPORT 2014 A Pan-European assessment of progress in the implementation of the ESSIP objectives. Brussels: SESAR JOINT UNDERTAKING; 2015. 